\title{
Modern approaches to study of soil covering with the use of information-communication techniques
}

\author{
Lebed V., Zalavskyi Yu.
}

NSC "O.N. Sokolovskyi Institute of soil science and agrochemistry», Chaikovska Str. 4, Kharkiv, 61024, Ukraine; e-mail: gruntpokrov@ukr.net

The purpose. To demonstrate necessity of ICT, which allows to assess more effectively state of soils for needs of simulation and mapping. Methods. Field plot technique - for study of soil covering according to State standard DSTU ISO 7921, description of soils was carried out according to State standard DSTU ISO 25177. Base correction of tapping points and importation of information on soils was realized in field by means of mobile application Collector for Arcgis. Analytical method - the gathered data were processed with the help of Arcgis for Desktop 10.2.2. Results. The data gathered during field probes in digital format enable to generate the sequenced I nntelligence system which can be used for construction of graphs, schemes and maps with visualization of characteristics of silos for assessment of their real state. Conclusions. Application modern ICT for study of soil covering enables to gather operatively and process data about state of soils, essentially facilitates creation of models and maps which can display factors of soil formation and distribution of soils.

Key words: soil coverin ng, soil reconnaissance, information-and-communication techniques, database, Smartphone, Collector for Arcgis.

Introduction. In our time, information and communication technologies (ICT) have become widely used to facilitate the collection, storage and transmission of digital data. It's actively used in the fields of computer science, telecommunications, education [1], but it's hardly used in soil science.

For storing information about the state of the soil, the use of paper media is not very comfortable and fast. Importantly to be quick and easy to note any data for their further processing in the field studies. The digital format avoids massive data tables included in the field magazine and provides more convenient processing of the received information in various software tools. As a result, an electronic database is formed, where is stored information of soil cover (location, morphology of soils, economic use, etc.), which is updated and used promptly.

The main goal of this publication is to demonstrate the possibility for ICT to more effectively assess the state of the soil by quantitative and qualitative characteristics for the needs of soil modeling and mapping.

Objects and methods of research. The use of ICT during the field studies was carried out on the territory of Okhtyrsky district of the Sumy region. The object of the study is within the first-loess terrace of the Vorskla River in the area nearby village Pology [2]. According to the soil-ecological zoning of Ukraine, the discovered area located in the forest-steppe temperately-humidified subzone in the Forest-Steppe zone [3].

The width of the first-loess terrace varies within $4-5 \mathrm{~km}$. The research area is near the transition to a second-loess terrace, which is represented by a significant ledge in the relief. The surface of a first-loess terrace is flat with minimal slopes. There are almost no closed relief lowering. The main parent rock is loess, which are represented in one layer and underlaied by ancient alluvial sands.

In the lowering is located between the first-loess and the second-loess terraces. There is the Gusinka river flow through. The river course is restructured as drainage irrigation channel. Thus, after flow regulation the groundwater level fell down. In result, the floodplain terrace was drained, where were wetter soils until that. At present there is a significant seasonal fluctuation of water levels, which affects to the water regime of soils [6].

The soil cover study was conducted in accordance with the general requirements of DSTU ISO 7921 [6]. To describe the soil, carried out in accordance with DSTU ISO 25177 [7], there were dug 7 soil pits (4 of them basic) with sampling, 4 drilled holes to designate groundwater level. Spatial reference data of selected 
points and noting information about the state of the soil occurred in the field with a smartphone on the Android OC with a built-in GPS-receiver and with the mobile application Collector for ArcGIS. In the desktop studies, the data collected was sent to ArcGIS for Desktop 10.2.2 software environment, which was used to create overview and soil maps.

This work involves the technological process, from the creation of a geodatabase to map representation in ArcGIS Online and, directly, its use for gathering field data and comparing the results.

On the studied area there are any hydromorphic soils, which are characterized by high content of humus in the upper layer and signs of gluing in the soil profile. The largest areas are gleyic chernozems soils in combination with mollic gleysols, and gleysols [8].

Basic soil pits have the following characteristics:

Soil pit №1is situated on a flat surface of a first-loess terrace along with main drainage channel. The depth of groundwater there $-193 \mathrm{~cm}$. Soil type is gleyic chernozem with silty clay loam texture on the loess. The width of the humus part of the profile is $105 \mathrm{~cm}$. The feature of this pit is little seasonal variation of groundwater level. It's less than $30 \mathrm{~cm}$.

Soil pit №2 is based on a lowering between first-loess and second-loess terraces. The depth of groundwater is $100 \mathrm{~cm}$. Soil type is mollic gleysol with silty clay loam texture on the marly loam. The width of the humus part of profile is $95 \mathrm{~cm}$. Variation of groundwater level is about $40 \mathrm{~cm}$.

Soil pit №3 is laid on a meadow near a drainage channel with a depth of groundwater $70 \mathrm{~cm}$. Soil type is gleysol with silty clay loam texture. The width of the humus part of the profile is $37 \mathrm{~cm}$. Variation of the groundwater level is $47 \mathrm{~cm}$.

Soil pit №4 is laid near the soil pit №3 on the higher hypsometric level with a height difference of $0.5 \mathrm{~m}$. The depth of groundwater is $137 \mathrm{~cm}$. Soil is mollic gleysols with silty clay loam texture. The width of the humus part of profile is $70 \mathrm{~cm}$. The feature of this pit is big seasonal variation of groundwater level about 80 $\mathrm{cm}$. It shows about large outflow of water in the summer.

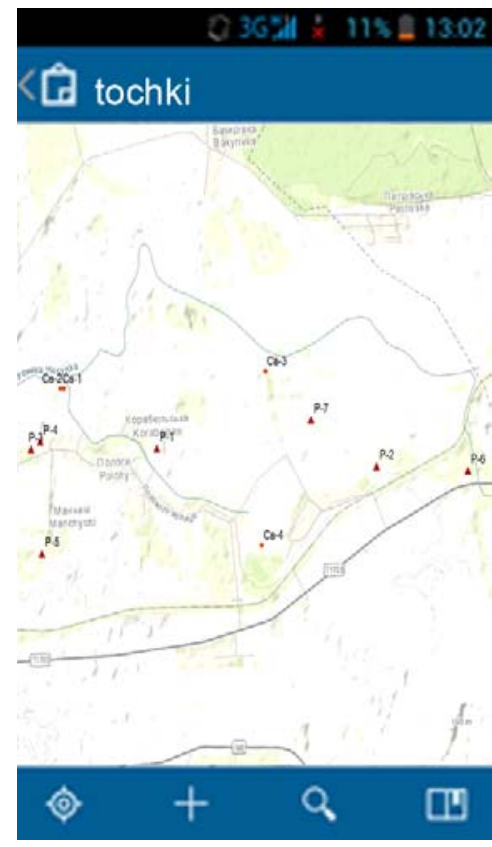

Fig.1 Screenshot of using Collector for Arcgis
Research results. The technological process of collecting information about soil condition with using ICT was divided onto two stages: desktop and field. For the implementation of the first stage, an original database with a data collection model in ArcGIS Desktop has been created and hosted as an object service on ArcGIS Online [10]. During field studies, which are the main stage for collecting and storage soil condition data, all received information was entered through the display of a mobile device in the Collector for ArcGIS (Fig.1). The database included a number of parameters defined during thepreparatory stage:

the number of the point of selection, the type of the point (soil pit, open test pit, well), $x, y$ - the coordinates of the

location (geographic coordinate system WGS84), the depth of soil's and water's sampling, the location of the soil pits, open test pits or wells, morphological andgenetic description of the profile (indexing of genetic horizons, structure, humidity, color), the previous name of the soil, additional information (Fig. 2). It should be noted that for a usingsmartphone in the field, preferable to have an access to the Internet (3G, 4G, WiFi) for the rapid transfer of information to the data storage [11]. 


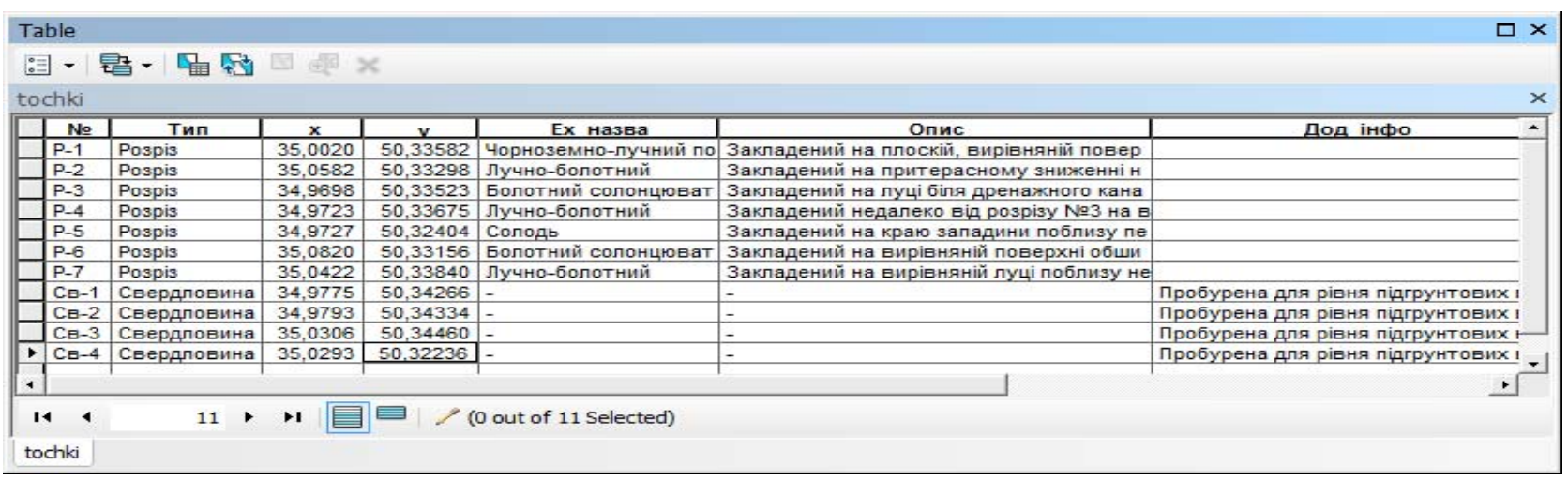

Fig. 2 A fragment of the geodatabase in the form of an attribute table

The collected data in a digital format allows us to form an ordered information system that can be used to construct graphs, charts and maps with visualization of soil characteristics to assessment their actual condition. It's also possible to use archival data of surveys of past years, which translated into digital format, in order to detect changes in the properties of soils in time.

\section{Conclusions}

Application of modern information and communication tools in studying of soil cover allows quickly collect and process soil condition data in different software products. This significantly facilitates the use of quantitative and qualitative indicators for the creation of models and maps of presentation soil formation factors and distribution of soils, also automates the process of large-scale soil cover survey.

\section{Bibliography}

1. Fominykh N.Y. Sutnist' ponyattya «Informatsiyno-komunikatsiyni tekhnolohiyi» ta yikh znachennya na suchasnomu etapi modernizatsiyi osvity URL:

http://www.nbuv.gov.ua/portal/soc_gum/pfto/2009_5/files/ped905_77.pdf [In Ukrainian].

2. Lebed V.V. (2015). Genezis i diagnostika polugidromorfnyih pochv lessovyih teras rek Ukrainyi. Mat-ly V s'ezda Belorusskogo obschestva pochvovedov i agrohimikov «Vosproizvodstvo plodorodiya pochv i in ohrana v usloviyah sovremennogo zemledeliya». Minsk, 22-26 iyunya 2015. S. 132-133. [In Russian].

3. Polupan M.I., Velychko V.V., Solovey V.B. (2015). Rozvytok ukrayins'koho ahronomichnoho gruntoznavstva: henetychni ta vyrobnychi aspekty: bonohrafiya. M.I. Polupana (Ed.). Kyiv: Ahrar. Nauka. 400 s. [In Ukrainian].

4. Lebed V.V. (2017). Vplyv pidgruntovykh vod na morfohenez profilyu gruntu zalezhno vid yikh rivnya ta mineralizatsiyi. Vseukrayins'kyy naukovo-praktychnyy kruhlyy stil dlya molodykh vchenykh "Teoriya $i$ praktyka innovatsiynykh rozrobok molodykh vchenykh u hruntovo-ahrokhimichniy nautsi». Kharkiv, 18-19 travnya 2017 r. S. 13-15. [In Ukrainian].

5. Rode A.A. (1965). Osnovy uchenija o pochvennoj vlage. Ch.1. Leningrad: Gidrometeoizdat. 663 s. [In Russian].

6. Yakist' gruntu. Velykomasshtabne doslidzhennya hruntovoho pokryvu. Zahal'ni vymohy : DSTU 7921:2015. Chynnyy vid 2016-09-01. Kharkiv: Tekhnichnyy komitet standartyzatsiyi TK 142 "Gruntoznavstvo». 2016. 8 s. (Natsional'ni standarty Ukrayiny). [In Ukrainian].

7. Yakist' gruntu. Pol'ovyy opys gruntu (ISO 25177:2008, IDT) : DSTU ISO 25177:2015. Chynnyy vid 2016-04-01. Kharkiv: Tekhnichnyy komitet standartyzatsiyi TK 142 «Gruntoznavstvo». 2016. 9 s. (Natsional'ni standarty Ukrayiny). [In Ukrainian].

8. Samojlova E.M. (1985). Lugovye pochvy lesostepi. Moskva: Izdatel'stvo MGU. 284 s. [In Russian].

6. Truskavets'kyy R.S., Tsapko L.Yu. (2016). Osnovy upravlinnya rodyuchistyu gruntiv. Kharkiv. 388 s. [In Ukrainian].

9. Zalavskyi Y.V. (2017). Informatsiyno-komunikatsiyni tekhnolohiyi yak zasib zboru danykh pro gruntovyy pokryv $\vee$ pol'ovykh umovakh dlya potreb kartohrafuvannya gruntiv. Vseukrayins'kyy naukovo-praktychnyy 
kruhlyy stil dlya molodykh vchenykh «Teoriya i praktyka innovatsiynykh rozrobok molodykh vchenykh $u$ hruntovo-ahrokhimichniy nautsi». Kharkiv, 18-19 travnya S. 5-6. [In Ukrainian].

10. Zalavskyi Y.V. (2017). Ispolzovanie informatsionno-kommunikatsionnyih tehnologiy dlya nuzhd pochvennogo obsledovaniya i kartografii pochv // Materialyi $\mathrm{m} / \mathrm{n}$ nauchno-prakt. konf. Molodyih uchenyih «Plodorodie pochv: otsenka, ispolzovanie i ohrana, vosproizvodstvo». Minsk, 26-30 iyunya $2017 \mathrm{~g}$. Izd-vo NAN Belarusi, Institut pochvovedeniya i agrohimii, S. 53-55. 